\title{
Health-related quality of life in adolescents and young adults with inflammatory bowel disease is associated with reduction in school and work productivity rather than physical impairment: a multidisciplinary study
}

\author{
Jane OBA ${ }^{1}$, Carlos W SOBRADO ${ }^{2,3}$, Aderson O M C DAMIÃO ${ }^{3}$, Matheus AZEVEDO ${ }^{3}$, Alexandre CARLOS $^{3}$, \\ Natália QUEIROZ², Claudio A LEN ${ }^{4}$, Ricardo K TOMA ${ }^{1}$, Mariana DEBONI ${ }^{1}$, Marcos J OZAKI ${ }^{1}$, \\ Flair José CARRILHO ${ }^{3}$, Sergio NAHAS $^{2}$ and Clovis A SILVA ${ }^{5}$
}

ABSTRACT - Background - Inflammatory bowel diseases (IBD), comprising Crohn's disease and ulcerative colitis, are chronic inflammatory diseases of the gastrointestinal tract that often have their onset among adolescents and young adults (AYA). IBD are characterized by episodes of active disease interspersed with periods of remission, and its activity is inversely correlated with health-related quality of life (HRQL). Objective - This study aimed to determine whether AYA in remission or with low IBD activity would exhibit HRQL similar to that of age-matched healthy individuals, and whether demographic and disease factors could affect HRQL using a 'patient-reported outcome' instrument. Methods - This study enrolled only AYA with IBD, with low activity. This research included five multidisciplinary clinics of two academic hospitals: Paediatric Gastroenterology, Gastroenterology, Coloproctology, Paediatric Rheumatology and Adolescent divisions, São Paulo, Brazil. A total of 59 AYA with IBD (age, 13-25 years) and 60 healthy AYA (age, 13-25 years) completed the Pediatric Quality of Life Inventory 4.0 and 36-Item Short-Form Health Survey questionnaires and the visual analogue scale (VAS) for pain. Demographic data, extra-intestinal manifestations, treatment, and outcomes regarding CD and UC were evaluated. Results - AYA with IBD and healthy controls were similar with respect to median ages (18.63 [13.14-25.80] years vs 20.5 [13.68-25.84] years, $P=0.598)$, proportion of female sex ( $42 \%$ vs $38 \%, P=0.654)$, and percentage of upper middle/middle Brazilian socioeconomic classes ( $94 \%$ vs $97 \%, P=0.596)$. The school/work score was significantly lower in AYA with IBD than in healthy controls (70 [10-100] vs 75 [5-100], $P=0.037)$. The 'general health-perception' score was significantly lower in AYA with IBD than in healthy controls (50 [10-80] vs 0 [25-90], $P=0.0002)$. The median VAS, FACES pain rating scale, and total VAS scores were similar between the two groups (2 [0-10] vs 3 [0-9], $P=0.214)$. No association between HRQL and clinical and demographic parameters was identified among IBD patients. Conclusion - AYA with low IBD activity reported poor HRQL in school/work and general health perception domains, which highlights a disability criterion in this vulnerable population.

Keywords - Inflammatory bowel diseases; Crohn's disease; colitis; ulcerative; health-related quality of life; quality of life; disability; adolescent; young adult.

\section{INTRODUCTION}

Inflammatory bowel disease (IBD), which includes Crohn's disease $(\mathrm{CD})$ and ulcerative colitis (UC), represents a collection of chronic idiopathic conditions of the gastrointestinal tract that are most often diagnosed in adolescents and young adults (AYA) ${ }^{(1)}$. IBD is characterised by episodes of remission and active disease that adversely affect health-related quality of life (HRQL) in $\mathrm{AYA}^{(2)}$. Disease activity is strongly and inversely correlated with HRQL; nonetheless, this important issue is rarely assessed in AYA as an endpoint in clinical trials ${ }^{(3)}$.
The most common signs and symptoms of IBD include rectal bleeding, diarrhoea, and particularly abdominal pain, which are recognised as important causes of poor HRQL ${ }^{(4,5)}$. Furthermore, IBD in adolescents is often more extensive and dynamic in progression than the adult-onset disease, leading to growth retardation, delayed puberty, weight loss, and surgical resections ${ }^{(1)}$. All of these have an adverse impact on the physical, psychosocial, and body image aspects of young adults, thereby worsening their $\operatorname{HRQL}^{(1,6,7)}$.

The International Organization for the Study of Inflammatory Bowel Diseases has recently issued guidelines on 'threat-to-target' strategies (STRIDE-II) that incorporated paediatric and adults

Faculdade de Medicina da Universidade de São Paulo, Gastroenterologia Pediátrica, São Paulo, SP, Brasil. ${ }^{2}$ Hospital das Clínicas da Faculdade de Medicina da Universidade de São

Paulo, Disciplina de Coloproctologia, São Paulo, SP, Brasil. ${ }^{3}$ Faculdade de Medicina da Universidade de São Paulo, Divisão de Gastroenterologia e Hepatologia Clínica, São Paulo, SP, Brasil. ${ }^{4}$ Universidade Federal de São Paulo, Reumatologia Pediátrica, São Paulo, SP, Brasil. ${ }^{5}$ Universidade de São Paulo, Instituto da Criança e do Adolescente, São Paulo, SP, Brasil.

Corresponding author: Clovis Silva. E-mail: clovis.silva@hc.fm.usp.br 
patients $^{(8)}$. In addition to clinical remission and endoscopic healing, the proposed long-term treatment targets encompass normalization of HRQL, absence of disability, and normal growth in adolescents. In this setting, these new targets are very appropriate to AYA with IBD (age, 13-25 years) because the transition period to adulthood is characterised by a highly unstable period and they often struggle in coping with a lifelong chronic disease ${ }^{(8)}$. Furthermore, adolescents exhibit more similarities in their HRQL judgments to young adults than to children ${ }^{(9)}$, and young adults show more resemblance to adolescents than to older groups ${ }^{(10)}$.

The World Health Organization defines HRQL as 'those aspects of self-perceived well-being that are related to or affected by the presence of disease or treatment' ${ }^{\prime(11)}$. HRQL has become an important outcome measure for the evaluation of an individual's adaptation to a chronic medical condition. A patient-reported outcome (PRO) is any report that directly comes from a patient, without interpretation by a clinician or anyone else. In this regard, HRQL is often evaluated using a PRO instrument to provide means for measuring treatment benefits by capturing concepts related to how a patient feels with respect to his/her health ${ }^{(12)}$. Generic and disease-specific tools have been developed to assess PROs in AYA with IBD.

In this context, we hypothesised that AYA with low IBD activity would exhibit HRQL similar to that of age-matched healthy individuals. The present study aimed to compare HRQL and pain disability between AYA with low IBD activity and age-matched healthy AYA and to identify the demographics and clinical characteristics associated with low HRQL in the IBD population of five multidisciplinary clinics.

\section{METHODS}

\section{Patients}

Only AYA with IBD in remission or low disease activity from July 2019 to February 2020 were selected for this cross-sectional study. This research included five multidisciplinary clinics of two academic hospitals followed in Paediatric Gastroenterology, Gastroenterology, Coloproctology, Paediatric Rheumatology and Adolescent divisions, São Paulo, Brazil. As our hospital is a quaternary center, patients come from all parts of the country. The healthy control group consisted of AYA selected from healthy students in the community. IBD classification was established in adolescents according to the Paris classification and the ESPGHAN revised Porto criteria for the diagnosis of $\mathrm{IBD}^{(13)}$ and in adults according to the Montreal classification ${ }^{(14)}$.

All patients with IBD, healthy controls, and legal guardians of adolescents signed an informed consent form. This study was approved by the Ethics Committee of our university hospital (CAAE: 82679518.2.0000).

\section{HRQL parameters}

HRQL assessment was performed using the Pediatric Quality of Life Inventory 4.0 (PedsQL ${ }^{\text {TM }} 4.0$ ). The PedsQL ${ }^{\text {TM }} 4.0$ is a generic, multidimensional, self-administered questionnaire that was validated in Brazilian Portuguese language for adolescents (age, 13-18 years) and young adults (age, 19-25 years) ${ }^{(15,16)}$ and consists of 23 items divided into four domains: physical capacity, emotional issues, social aspects, and school/work activities, systematically assessed in the last month of study entry. These measures provided a total HRQL score and two summary scores: physical health (comprising the physical health domain score) and psychosocial health (comprising the emotional, social, and school functioning domain scores). A five-point Likert scale ranging from 'never' to 'almost always' was used, and items were scored on a 0-100 metric scale. High scores indicated the best HRQL parameters; if $>50 \%$ of scale items were missing, the scale score was not computed ${ }^{(15)}$. Finally, for qualitative analysis, the patients could express their thoughts regarding their disease and treatment at the end of the questionnaire, which were written in their own words.

The 36-Item Short-Form Health Survey (SF-36) is also a generic, multidimensional, self-administered questionnaire for adults. It is validated in Brazilian Portuguese language and consists of 36 items divided into eight domains: physical functioning, role physical (i.e., role limitations due to physical difficulties), role emotional (i.e., role limitations due to emotional difficulties), vitality/energy, mental health, social functioning, bodily pain, and general health perception. This validated instrument was applied only to young adults with IBD for HRQL evaluation ${ }^{(17)}$. Additionally, one singleitem 'health change' evaluated differences in the state of health over the past year. The final score ranged from 0 to 100, with higher scores indicating the best HRQL parameters.

\section{Functional pain disability}

The visual analogue scale (VAS) and FACES pain rating scale (FPRS), which are validated subjective measures of acute and chronic pain intensity, were used to evaluate AYA with IBD. VAS scores were recorded by making a handwritten mark on a $10-\mathrm{cm}$ line at $1-\mathrm{cm}$ intervals, which represents a continuum between 'no pain' and 'worst pain'. The FPRS presents five hand-drawn faces that gradually increase pain expression from neutral to higher pain levels ${ }^{(18)}$.

\section{Demographic and clinical data}

Demographic data, clinical features, laboratory findings, treatments, and outcomes were carefully evaluated according to an extensive standardised protocol. Demographic data included current age, sex, school years, body mass index (BMI), disease duration, and Brazilian socioeconomic class $^{(19)}$. The following extra-intestinal manifestations were systematically assessed: uveitis, episcleritis, erythema nodosum, pyoderma gangrenosum, and arthritis/arthralgia. The erythrocyte sedimentation rate and $\mathrm{C}$ reactive protein (CRP) level were evaluated using the Westergren method and nephelometry, respectively.

Only patients in remission or with mild activity were selected, and disease activity was defined using the following four indices: (i) Pediatric Crohn's Disease Activity Index (PCDAI), with scores ranging from 0 to 100 points (remission, $\leq 10$; mild activity, $10 \leq 30)^{(20)}$; (ii) Pediatric Ulcerative Colitis Activity Index (PUCAI), with scores ranging from 0 to 85 points (remission, $\leq 10$; mild activity, $10 \leq 34)^{(20)}$; (iii) Harvey-Bradshaw index for adult CD (remission, $<5$; mild disease activity, 5-7)(21); and (iv) partial Mayo index for adult UC (remission, <2; mild disease activity, 2-4) ${ }^{(22)}$.

Additionally, the following treatments for IBD were recorded: 5-ASA drugs, corticosteroids, immunomodulator drugs (azathioprine, 6-mercaptopurine, and methotrexate), and biologic agents (infliximab, adalimumab, and vedolizumab). Outcomes, previous gut surgery, and malignancy were also analysed.

\section{Statistical analyses}

Statistical analyses were performed using SPSS software version 
22.0 (IBM Corp., Armonk, NY, USA). The Mann-Whitney test was used to compare continuous variables with asymmetric distribution. Scores are presented as medians (maximum and minimum values), whereas nominal variables are expressed as frequencies. Fisher's exact test was used to compare the data between the two groups. The $P$-values were set at $5 \%(P<0.05)$ for all statistical tests. A multivariate analysis was performed to evaluate IBD activity, treatments, and outcomes with respect to HRQL in AYA with IBD.

\section{RESULTS}

TABLE 1 summarises the demographic data of patients with IBD and healthy controls. The median current ages of AYA with IBD and healthy controls were similar $(18.63$ [13.14-25.80] years vs 20.53 [13.68-25.84] years, $P=0.598$ ). The proportion of female sex was similar between the two groups ( $42 \%$ vs $38 \%, P=0.654)$. Less than $8 \%$ out of 26 adolescents with IBD were below the third percentile in height. IBD patients were similar in terms of height and BMI to the healthy controls. No differences in school years (11 [8-17] vs 15 [6-15] years, $P=0.072$ ) and upper middle/middle Brazilian socioeconomic classes ( $94 \%$ vs $97 \%, P=0.596$ ) were observed between the two groups (TABLE 1).

TABLE 2 presents the PedsQL ${ }^{\text {TM }} 4.0$ and SF-36 domains, VAS, and FPRS scores of patients with IBD, as compared to those of healthy controls. The school/work domain score with PedsQL ${ }^{\text {TM }} 4.0$ was significantly lower in AYA with IBD than in healthy controls (70 [10-100] vs 75 [5-100], $P=0.037$ ). Overall, $80 \%$ of AYA with IBD provided additional information regarding their complaints about long-term treatment. The main reported reasons for the impaired QoL were frequent medical appointments, time-consuming biological infusions, long-term treatment, and multiple procedures that affect patients' frequency in school or at permanent work. As for SF-36, the general health perception domain score (50 [10-80] vs 70 [25-90], $P=0.0002$ ) was significantly lower in the adult IBD group than in the healthy control group. The score for the additional item perception of 'health change' was significantly higher in the IBD group than in the healthy control group (75 [25-100] vs 50 [25-100], $P=0.042]$. No differences in other parameters were observed between AYA with IBD and healthy controls $(P>0.05$, TABLE 2).

Among patients with $\mathrm{CD}$ and $\mathrm{UC}$, young adult with $\mathrm{CD}$ had a significantly higher perception of 'health change' item in SF-36 (75 [25-100) vs 62 [25-100], $P=0.042$; TABLE 3). All the domains in SF-36 were similar between both groups, as were the PedsQL ${ }^{\mathrm{TM}}$ 4.0 domain, VAS, FPRS, and total VAS scores $(P>0.05)$.

Demographic and clinical data of patients with $C D$ and UC are shown in TABLE 4. Patients with CD had a significantly shorter disease duration (42.5 [1.0-247.0] months vs 78.0 [12.0209.0] months, $P=0.014$ ) and lower proportion of female patients $(32 \%$ vs $62 \%, P=0.025)$ than patients with UC. The frequency of overlap syndrome with autoimmune sclerosing cholangitis was significantly lower in patients with $\mathrm{CD}$ than in patients with UC $(0 \%$ vs $19 \%, P=0.013)$. Anaemia was diagnosed in $6 \%$ of all patients, hypoalbuminaemia (albumin $<3.5 \mathrm{~g} / \mathrm{dL}$ ) in $1 \%$, and high CRP level $(>5 \mathrm{mg} / \mathrm{dL})$ in $30 \%$. The frequencies of prednisone and 5 -ASA treatments were significantly lower in patients with $\mathrm{CD}$ than in patients with UC ( $5 \%$ vs $28 \%, P=0019$ and $8 \%$ vs $81 \%$, $P=0.001$, respectively). The rate of previous gut surgery was significantly higher in patients with $\mathrm{CD}$ than in patients with UC $(47 \%$ vs $9 \%, P=0.004)$.
TABLE 1. Demographic data of inflammatory bowel disease patients and healthy controls.

\begin{tabular}{lccc}
\hline Variables & $\begin{array}{c}\text { IBD patients } \\
(\mathbf{n}=59)\end{array}$ & $\begin{array}{c}\text { Healthy } \\
\text { controls }(\mathbf{n}=60)\end{array}$ & $\boldsymbol{P}$ \\
\hline Demographic data & & & \\
Current age, years & 18.63 & 20.53 & $0.598^{*}$ \\
Female sex & $(13.14-25.80)$ & $(13.68-25.84)$ & $25(42)$ \\
BMI, kg/m & 20.05 & $23(38)$ & $0.654 \dagger$ \\
School, years & $(14.50-30.88)$ & $(15.90-28.10)$ & $0.659^{*}$ \\
$\begin{array}{l}\text { Upper } \\
\text { middle/middle }\end{array}$ & $11(8-17)$ & $15(6-15)$ & $0.072^{*}$ \\
socio-economic classes & $33 / 35(94)$ & $39 / 40(97)$ & $0.596 \dagger$ \\
\hline
\end{tabular}

BMI: body mass index, *Mann-Whitney test, $\uparrow$ Fisher exact test. Results are presented in median (minimum and maximum values) or $\mathrm{n}(\%)$.

TABLE 2. Pediatric Quality of Life Inventory 4.0 (PedsQL $^{\mathrm{TM}} 4.0$ ), Pain VAS, Faces Pain Rating Scale and Short-Form Health Survey (SF-36) scores according to reports of inflammatory bowel disease patients and healthy controls.

\begin{tabular}{|c|c|c|c|}
\hline Variables & $\begin{array}{l}\text { AYA with } \\
\operatorname{IBD}(\mathrm{n}=59)\end{array}$ & $\begin{array}{l}\text { Healthy } \\
\text { controls } \\
(\mathrm{n}=60)\end{array}$ & $P^{*}$ \\
\hline \multicolumn{4}{|l|}{ PedsQL ${ }^{\mathrm{TM}} 4.0$ score } \\
\hline Physical health score & $\begin{array}{c}81.3 \\
(12.5-100)\end{array}$ & $\begin{array}{c}87.5 \\
(34.3-100)\end{array}$ & 0.229 \\
\hline $\begin{array}{l}\text { Psychosocial health } \\
\text { score }\end{array}$ & $\begin{array}{c}71.7 \\
(18.3-100)\end{array}$ & $\begin{array}{c}73.3 \\
(25-100\end{array}$ & 0.6014 \\
\hline Emotional & $60.0(0-100)$ & $65(20-100)$ & 0.773 \\
\hline Social & $90.0(40-100)$ & $82.5(10-100)$ & 0.275 \\
\hline School/work & $70.0(10-100)$ & $75(5-100)$ & 0.037 \\
\hline Total score & $\begin{array}{c}74.4 \\
(20-100)\end{array}$ & $\begin{array}{c}77.2 \\
(41.3-100)\end{array}$ & 0.756 \\
\hline Pain VAS scale & $2.0(0-10)$ & $1.0(0-7)$ & 0.111 \\
\hline Faces pain rating scale & $2.0(0-10)$ & $2.0(0-8)$ & 0.191 \\
\hline Total VAS scale & $2.0(0-10)$ & $1.5(0-8)$ & 0.190 \\
\hline SF-36 score & $\begin{array}{l}\text { Young adults } \\
\text { with IBD } \\
(\mathrm{n}=33)\end{array}$ & $\begin{array}{l}\text { Heathy } \\
\text { controls } \\
(n=39)\end{array}$ & $P^{*}$ \\
\hline Physical functioning & $95(10.0-100)$ & $95(30-100)$ & 0.255 \\
\hline $\begin{array}{l}\text { Role limitation due to } \\
\text { physical health }\end{array}$ & $100(0-100)$ & $100(0-100)$ & 0.186 \\
\hline $\begin{array}{l}\text { Role limitation due to } \\
\text { emotional problems }\end{array}$ & $67(0-10)$ & $67(0-100)$ & 0.971 \\
\hline Energy/vitality & $60(0-100)$ & $60(15-90)$ & 0.918 \\
\hline Mental health & $64(4-88)$ & $76(20-96)$ & 0.077 \\
\hline Social functioning & $75(0-100)$ & $88(13-100)$ & 0.106 \\
\hline Bodily pain & $80(0-100)$ & $80(33-100)$ & 0.927 \\
\hline $\begin{array}{l}\text { General health } \\
\text { perceptions }\end{array}$ & $50(10-80)$ & $70(25-90)$ & 0.0002 \\
\hline Total score & $552(97-748)$ & $648(243-763)$ & 0.122 \\
\hline
\end{tabular}

VAS: visual analogue scale; AYA: adolescents and young adults. *Mann-Whitney test. Results are presented in median (minimum and maximum values). 
TABLE 3. Pediatric Quality of Life Inventory 4.0 (PedsQL $\left.{ }^{\mathrm{TM}} 4.0\right)$ and Medical Outcomes Short-Form Health Survey (SF-36) scores according to the reports of Crohn disease (CD) and ulcerative colitis (UC) patients.

$\begin{array}{lcc}\text { AYA with } & \text { AYA with } \\ \text { Variables } & \text { CD } & \text { UC } \\ & & (n=21)\end{array} \quad P^{*}$

PedsQL $L^{\mathrm{TM}} 4.0$ score

\begin{tabular}{|c|c|c|c|}
\hline Physical & $\begin{array}{c}82.8 \\
(31.3-100)\end{array}$ & $\begin{array}{c}81.3 \\
(12.50-100)\end{array}$ & 0.993 \\
\hline Psychosocial Health & $75.3(29-100)$ & $73.3(16-100)$ & 0.456 \\
\hline Emotional & $62.5(0-100)$ & $60.0(0-100)$ & 0.680 \\
\hline Social & $\begin{array}{c}90.0 \\
(45.0-100.0)\end{array}$ & $\begin{array}{c}90.0 \\
(40.0-100)\end{array}$ & 0.783 \\
\hline School/work & $70(25-100)$ & $65(10-100)$ & 0.165 \\
\hline Total score & $\begin{array}{c}76.1 \\
(37.5-100)\end{array}$ & $\begin{array}{c}73.9 \\
(20-100)\end{array}$ & 0.825 \\
\hline Pain VAS scale & $2.0(0-10)$ & $2.0(0-8)$ & 0.894 \\
\hline Faces pain rating scale & $2.0(0-10)$ & $2.0(0-8)$ & 0.756 \\
\hline Total VAS scale & $4.0(0-10)$ & $4(0-10)$ & 0.896 \\
\hline SF-36 score & $\begin{array}{l}\text { Young adults } \\
\text { with CD } \\
(\mathrm{n}=19)\end{array}$ & $\begin{array}{c}\text { Young adults } \\
\text { with UC } \\
(n=14)\end{array}$ & $P^{*}$ \\
\hline Physical functioning & $95(25-100)$ & $\begin{array}{c}97.5 \\
(10-100)\end{array}$ & 0.369 \\
\hline $\begin{array}{l}\text { Role limitation due to } \\
\text { physical health }\end{array}$ & $75(0-100)$ & $100(0-100)$ & 0.641 \\
\hline $\begin{array}{l}\text { Role limitation due to } \\
\text { emotional problems }\end{array}$ & $67(0-100)$ & $67(0-100)$ & 0.674 \\
\hline Energy/vitality & $60(0-85)$ & $60(20-100)$ & 0.465 \\
\hline Mental health & $72(4-88)$ & $62(32-88)$ & 0.454 \\
\hline Social functioning & $75(25-100)$ & $88(13-100)$ & 0.094 \\
\hline Bodily pain & $80(33-100)$ & $80(0-100)$ & 0.839 \\
\hline $\begin{array}{l}\text { General health } \\
\text { perceptions }\end{array}$ & $50(15-80)$ & $50(10-80)$ & 0.522 \\
\hline Total score & $\begin{array}{c}575 \\
(107-711)\end{array}$ & $\begin{array}{c}551 \\
(97-748)\end{array}$ & 0.941 \\
\hline
\end{tabular}

CD: Crohn disease; UC: ulcerative colitis; AYA: adolescents and young adults. *Mann-Whitney test. Results are presented in median (minimum and maximum values).
TABLE 4. Demographic data, cumulative extra-intestinal (EI) manifestations, overlap autoimmune diseases, disease activity parameters, treatments and outcomes in CD and UC patients.

\begin{tabular}{|c|c|c|c|}
\hline Variables & $\begin{array}{l}\text { AYA with } \\
\text { CD }(n=38)\end{array}$ & $\begin{array}{l}\text { AYA with } \\
\text { UC patients } \\
(\mathrm{n}=21)\end{array}$ & $P$ \\
\hline \multicolumn{4}{|l|}{ Demographic data } \\
\hline Current age, years & $\begin{array}{c}17.9 \\
(13.5-25.8)\end{array}$ & $\begin{array}{c}19.2 \\
(13.1-25.5)\end{array}$ & $0.680 *$ \\
\hline Disease duration, months & $\begin{array}{c}42.5 \\
(1.0-247.0)\end{array}$ & $\begin{array}{c}78.0 \\
(12.0-209.0)\end{array}$ & $0.014 *$ \\
\hline Female sex $(\%)$ & $12(32)$ & $13(62)$ & $0.025 \dagger$ \\
\hline $\mathrm{BMI}, \mathrm{kg} / \mathrm{m}^{2}$ & $\begin{array}{c}19.9 \\
(14.5-28.0)\end{array}$ & $\begin{array}{c}20.08 \\
(15.30-30.8)\end{array}$ & 0.447 \\
\hline School, years & $10(8-17)$ & $12(8-15)$ & 0.184 \\
\hline $\begin{array}{l}\text { Upper middle/middle } \\
\text { socio-economic classes }\end{array}$ & $21 / 22(95)$ & $12 / 13(92)$ & 1.000 \\
\hline \multicolumn{4}{|l|}{ Cumulative EI manifestations } \\
\hline Uveitis/episcleritis & $3(8)$ & $2(9)$ & $1.000 \dagger$ \\
\hline $\begin{array}{l}\text { Erythema nodosum/ } \\
\text { pyoderma } \\
\text { gangrenosum }\end{array}$ & $3(8)$ & $2(9)$ & $1.000 \dagger$ \\
\hline Arthritis/arthralgia & $10(26)$ & $5(24)$ & $1.000 \dagger$ \\
\hline \multicolumn{4}{|l|}{ Overlap syndromes } \\
\hline Autoimmune hepatitis & $0(0)$ & $1(5)$ & $0.356 \dagger$ \\
\hline $\begin{array}{l}\text { Autoimmune sclerosing } \\
\text { cholangitis }\end{array}$ & $0(0)$ & 4 (19) & $0.013 \dagger$ \\
\hline
\end{tabular}

Current disease activity parameters Harvey-Bradshaw score for aCD

Remission and mild activity $\mathrm{n}(\%)$

$19(32 \%)$

PCDAI score for pCD

Remission and mild activity n (\%)

$19(32 \%)$

Mayo score for aUC

Remission and mild activity n (\%)

$14(24 \%)$

PUCAI score for pUC

Remission and mild activity n (\%)

$7(12 \%)$

Current treatments

$\begin{array}{lccc}\text { Prednisone } & 2(5) & 6(28) & 0.019 \dagger \\ \text { 5-aminosalicylic acid } & 3(8) & 17(81) & 0.0001 \dagger \\ \text { Azathioprine } & 24(63) & 15(71) & 0.775 \dagger \\ \text { Methotrexate } & 5(13) & 1(5) & 0.407 \dagger \\ \text { Infliximab } & 19(50) & 5(24) & 0.059 \dagger \\ \text { Adalimumab } & 9(24) & 4(19) & 0.754 \dagger \\ \text { Vedolizumab } & 0(0) & 1(5) & 0.356 \dagger\end{array}$

Outcomes

\begin{tabular}{lccc} 
Previous gut surgery & $18(47)$ & $2(9)$ & $0.004 \dagger$ \\
Malignancy & $0(0)$ & $0(0)$ & $1.000 \dagger$ \\
\hline
\end{tabular}

BMI: body mass index; EI: extra-intestinal; CD: Crohn disease; UC: ulcerative colitis; AYA adolescents and young adults; PCDAI: Pediatric Crohn's Disease Activity Index; PUCAI Pediatric Ulcerative Colitis Activity Index; Disease severity: Harvey-Bradshaw, PCDAI, Mayo. a: adult, p: pediatric, $*$ Mann-Whitney test, $†$ Fisher exact test. Results are presented in n $(\%)$ or median (minimum and maximum values). 
Further analysis of PedsQL ${ }^{\mathrm{TM}} 4.0$ scores in adolescents with IBD aged $\leq 18$ years compared to young adults with IBD aged $>19-25$ years showed similar medians in both groups for physical (81.3 [12.5-100] vs 87.5 [34.3-100], $P=0.229)$, emotional (65 $[0-100]$ vs 65 [25-100], $P=0.857)$, social $(95$ [40-100] vs 80 [45-100], $P=0.502)$, school/work scores $(70[15-100]$ vs $65[10-100], P=0.810)$, and total score (78 [43-100] vs 73 [20-100], $P=0.727)$. The median VAS ( 2 [0-10] vs 3 [0-9], $P=0.238]$, FPRS $(2[0-10]$ vs 2 [0-8], $P=0.435]$, and total VAS scores $(2$ [0-10] vs 3 [0-9], $P=0.214]$ were similar between both groups. Furthermore, multivariate analysis revealed no association between HRQL and clinical and demographic parameters.

\section{DISCUSSION}

We reported the impact of low IBD activity on the HRQL of AYA population at a large referral centre in Brazil. We identified that AYA with well-controlled IBD had significantly lower HRQL than healthy controls with respect to psychosocial scores, specifically in the school/work and general health perception domains. In line with the findings of other studies in the literature, lower HRQL scores in the school/work domain were also observed and described among adolescents and adults with $\operatorname{IBD}^{(6,23,24)}$. These issues reflect the challenges in integrating AYA with IBD into the society, affect their job opportunities and future aspirations, lead to personal absenteeism in school, reduce work productivity, and cause financial burden on the healthcare $\operatorname{system}^{(7,25,26)}$. Moreover, the qualitative sampling assessment provided additional relevant insights to this study when patients reported that, frequent medical appointments, time-consuming biological infusions, long-term treatment, and multiple procedures unquestionably impair their frequency in school or at permanent work. These observations highlighted a disability criterion and emphasised the importance of developing validated disability questionnaires for AYA with IBD in the future. Other domains of PedsQL ${ }^{\text {TM }} 4.0$ and SF-36 were similar between both groups, as were the VAS, FPRS, and total VAS scores.

General health perception refers to patients' assessment of their own personal health ${ }^{(17)}$. Lower scores for this domain among young adults with IBD, as compared to healthy controls, should reflect patients' experience with the disease and its treatment. No differences in all domains of PedsQL ${ }^{\text {TM }} 4.0$ and SF-36 as well as in the pain scales were observed between patients with $C D$ and UC, suggesting that they had similar HRQL in our study. Analysis of the additional item 'health change over the past year' showed that AYA with UC had lower scores than AYA with CD. This perception should be influenced by the predominance of female sex, longer disease duration, and use of steroids, as observed by other authors ${ }^{(27,28)}$. Interestingly, previous gut surgery did not negatively influence the HRQL of AYA with CD, suggesting that resection for the treatment of severe complications such as strictures and appropriate drainage of fistulas may improve a previous disabling condition.

In the present study, pain scores (VAS and FPRS) were similar between AYA with IBD and healthy controls and also between the $\mathrm{CD}$ and UC groups. Abdominal pain is often associated with disease flares. Furthermore, pain is a category of disability and is consistently associated with emotional distress, anxiety, depression, and cognitive illness that impairs patients with IBD across all ages ${ }^{(5,29,30)}$.
The age limit for paediatric care is debated and has recently been extended. The American Academy of Pediatrics has suggested an upper age limit of 21 years for adolescence ${ }^{(31)}$. In contrast, other authors have suggested that the adolescent age should range from 10 to 25 years, based on brain growth and contemporary patterns of neurocognitive myelin synthesis, following the recommendations of the Institute of Medicine and National Research Council of the United States ${ }^{(32)}$. In the present study, we used a wide cut-off age range (13-25 years) because this period also has similar socioemotional vulnerability to biological, psychological, social, and cognitive development. Moreover, at the beginning of this stage, young adults are nearly finishing high school, living with their parents, and engaging in romantic relationships. These milestones may be affected in patients with chronic conditions such as IBD. Our hospital is establishing the model recommended by "European Crohn's and Colitis Organisation", with a joint adolescent-adult clinic, enrolling five multidisciplinary clinics (Paediatric Gastroenterology, Gastroenterology, Coloproctology Rheumatology and Adolescents) as part of a transition program $^{(33)}$.

It is important to emphasise that most patients enrolled in our study had good control of inflammatory activity, probably due to the implementation of effective therapies for IBD management. Disease activity is not the only factor that influences HRQL; patients' knowledge and concerns about the disease as well as their coping may also positively influence $\mathrm{HRQL}^{(34)}$. It is noteworthy that less than $8 \%$ of adolescents exhibited growth failure (height for age below the third percentile) and were similar to healthy controls with respect to growth and BMI. Considering that school/work comprises an important part of disability, general health perception is the patients' own experience, and pain scales are more related to disease activity, there is an urgent need for future studies to explore disabilities in this vulnerable population. Moreover, it is essential to underline that IBD symptoms in AYA are not only driven by disease activity; assessment of differential diagnosis, including irritable bowel syndrome and small intestinal bacterial overgrowth, was outside the scope of the present study.

The present study had some limitations. The small populations for both diseases affecting young patients may preclude the analysis of the impact of HRQL and disability parameters, particularly in specific populations with UC and CD. Additionally, disease-specific IBD instruments for adolescents and adults with IBD were not assessed. At study entry, a disease-specific health-related qualityof-life questionnaire developed for use in pediatric inflammatory bowel disease (IMPACT-III) was not a validated tool available in Brazilian Portuguese language. Disease activity was assessed using clinical scores only because faecal calprotectin, a non-invasive objective inflammatory biomarker, is not included as part of routine screening at our hospital; hence, we did not include it in this study. It is noteworthy that $20 \%$ of patients in our sample underwent colonoscopy or cross-sectional imaging at within one month of the questionnaire's application. It was not feasible to frequently repeat these procedures owing to their cost and/or invasive nature. We did not consider these data despite being a relevant target because of the insufficient sample size.

Notwithstanding these limitations, the strength of the present study was the systematic assessment of HRQL and self-reported pain disability parameters in AYA with IBD from five multidisciplinary clinics of two academic hospitals: paediatric gastroenterology, gastroenterology, coloproctology, paediatric rheumatology and adolescent divisions. Considering 'patient-centred care', PROs 
have become the current standard for the assessment of HRQL and disabilities in AYA with IBD. PedsQL ${ }^{\text {TM }}$ 4.0, SF-36, and pain scales are self-assessment tools for PROs that are feasible and easy to use to capture disease control from the patients' perspective ${ }^{(15-17)}$. Furthermore, generic questionnaires enabled us to compare AYA with IBD and healthy controls. In particular, PedsQL ${ }^{\text {TM }} 4.0$ showed good correlation with IMPACT-III, a specific tool, in previous study ${ }^{(35)}$. Additionally, the healthy controls with similar age, sex, school years, and socioeconomic class to AYA with IBD were relevant herein, as these demographic data may influence HRQL parameters. These findings indicate that multidisciplinary teams are recommended for all patients with IBD, irrespective of their current disease activity, in order to clarify the patients' situation and identify aspects that require action.

In conclusion, AYA with IBD constitute a distinct group; given their complex disease phenotype and specific concerns about medications, they find themselves at a period of transition from childhood to adulthood, which is characterised by considerable psychosocial changes. Our multidisciplinary study showed that effective control of inflammatory activity in AYA with IBD is insufficient to improve HRQL. Lower HRQL in school/work and general health perception domains highlights the need to further explore disabilities in this vulnerable population. Additionally, international multicentre studies that include global comparisons of HRQL and disabilities among AYA with IBD using validated questionnaires are warranted to better clarify this issue.

\section{ACKNOWLEDGEMENTS}

The authors acknowledge Dr. Ulysses Doria Filho for his statistical analysis supervisor, and Luisa Leite Barros and Luciane Milani for physician supervision.

\section{Authors' contribution}

Oba J, Sobrado CW and Silva CA contributed to study conception and design. All authors critically reviewed the manuscript, contributed important intellectual content, and approved the final manuscript version for submission. All authors agree to be accountable for all aspects of the work, and Oba J holds overall responsibility for the content and integrity of this paper.

\section{Orcid}

Jane Oba: 0000-0003-4993-6515.

Carlos W Sobrado: 0000-0003-4486-9894

Aderson O M C Damião: 0000-0001-7584-7351.

Matheus Azevedo: 0000-0001-5487-9418.

Alexandre Carlos: 0000-0001-6485-7968.

Natália Queiroz: 0000-0003-2857-0825.

Claudio Len: 0000-0001-8636-1744.

Ricardo Toma: 0000-0003-3792-8075.

Mariana Deboni: 0000-0002-9702-189X.

Marcos J Ozaki: 0000-0001-9478-7630.

Flair José Carrilho: 0000-0002-7682-3105.

Sergio Nahas: 0000-0002-2268-4146.

Clovis Silva: 0000-0001-9250-6508.

Oba J, Sobrado CW, Damião AOMC, Azevedo M, Carlos A, Queiroz N, Len CA, Toma RK, Deboni M, Ozaki MJ, Carrilho FJ, Nahas S, Silva CA. A qualidade de vida relacionada à saúde em adolescentes e adultos jovens com doença inflamatória intestinal está mais associada à redução na produtividade escolar e no trabalho do que ao comprometimento físico: um estudo multidisciplinar. Arq Gastroenterol. 2021;58(4):541-7.

RESUMO - Contexto - As doenças inflamatórias intestinais (DII), que englobam a doença de Crohn e a colite ulcerativa, são doenças inflamatórias crônicas do trato gastrointestinal que frequentemente se manifestam em adolescentes e adultos jovens (AAJ). As DII são caracterizadas por episódios de doença ativa intercalados com períodos de remissão, e sua atividade se correlaciona inversamente com a qualidade de vida relacionada à saúde (QVRS). Objetivo - Este estudo teve como objetivo determinar se AAJ em remissão ou com baixa atividade de DII exibiria QVRS semelhante à de indivíduos saudáveis pareados por idade, e se fatores demográficos da doença poderiam afetar a QVRS usando um instrumento de medidas de desfecho relatadas pelo paciente. Métodos - Este estudo envolveu apenas AAJ com DII, com baixa atividade. Esta pesquisa incluiu cinco clínicas multidisciplinares de dois Hospitais Universitários: Divisões de Gastroenterologia Pediátrica, Gastroenterologia, Coloproctologia, Reumatologia Pediátrica e Adolescentes, São Paulo, Brasil. Um total de 59 AAJ com DII (13-25 anos de idade) e 60 AAJ controle saudáveis (13-25 anos de idade) responderam os questionários Pediatric Quality of Life Inventory 4.0 e 36-Item Short-Form Health Survey e as escalas visuais de dor. Dados demográficos, manifestações extra intestinais, tratamentos e desfechos da doença de Crohn e a colite ulcerativa foram avaliados. Resultados - AAJ com DII e os controles saudáveis foram grupos semelhantes com relação à média de idade $(18,63[13,14-25,80]$ vs $20,5[13,68-25,84]$ anos, $P=0,598)$, quanto à proporção de pacientes do sexo feminino ( $42 \%$ vs $38 \%, P=0,654)$, e quanto à porcentagem da classe socioeconômica brasileira média elevada/ média $(94 \%$ vs $97 \%, P=0,596)$. Os escores escola/trabalho foram significativamente mais baixos nos AAJ com DII do que nos controles saudáveis (70 [10-100] vs 75 [5-100], $P=0,037)$. O escore 'percepção geral de saúde' foi significativamente mais baixo nos AAJ com DII do que no agrupamento controle saudável (50 [10-80] vs 0 [25-90], $P=0,0002)$. As escalas de avaliação visual de dor foram semelhantes entre os dois grupos (2 [0-10] vs $3[0-9], P=0,214)$. Nenhuma associação entre QVRS e parâmetros clínicos e demográficos foi identificada entre os pacientes com DII. Conclusão - AAJ com baixa atividade das DII relataram baixa QVRS nos domínios da escola/trabalho e percepção geral da saúde, o que destaca um critério de incapacidade nesta vulnerável população.

Palavras-chave - Doenças inflamatórias intestinais; doença de Crohn; colite ulcerativa; qualidade de vida relacionada à saúde; qualidade de vida; incapacidade; deficiência; adolescente; adulto jovem. 


\section{REFERENCES}

1. Rosen MJ, Dhawan A, Saeed SA. Inflammatory bowel disease in children and adolescents. Vol. 169, JAMA Pediatrics. 2015;169:1053-60.

2. Moradkhani A, Beckman LJ, Tabibian JH. Health-related quality of life in inflammatory bowel disease: Psychosocial, clinical, socioeconomic, and demographic predictors. J Crohn's Colitis. 2013;7:467-73.

3. Gumidyala AP, Greenley RN. Correlates of health-related quality of life in pediatric inflammatory bowel disease: A cumulative risk model approach. J Pediatr Psychol. 2014;39:55-64

4. Peyrin-Biroulet L, Sandborn W, Sands BE, Reinisch W, Bemelman W, Bryant R $\mathrm{V}$, et al. Selecting Therapeutic Targets in Inflammatory Bowel Disease (STRIDE): Determining Therapeutic Goals for Treat-to-Target. Am J Gastroenterol. 2015;110:1324-38.

5. Greenley RN, Kunz JH, Schurman JV, Swanson E. Abdominal pain and health related quality of life in pediatric inflammatory bowel disease. J Pediatr Psychol. 2013;38:63-71.

6. Eloi C, Foulon G, Bridoux-Henno L, Breton E, Pelatan C, Chaillou E, et al. Inflammatory Bowel Diseases and School Absenteeism. J Pediatr Gastroenterol Nutr. 2019;68:541-6.

7. de S B Fróes R, Carvalho ATP, Antonio AJ, de Barros Moreira AMH, Moreira JPL, Luiz RR, et al. The socio-economic impact of work disability due to inflammatory bowel disease in Brazil. Eur J Heal Econ. 2018;19:463-70.

8. Turner D, Ricciuto A, Lewis A, D'Amico F, Dhaliwal J, Griffiths AM, et al. STRIDE-II: An Update on the Selecting Therapeutic Targets in Inflammatory Bowel Disease (STRIDE) Initiative of the International Organization for the Study of IBD (IOIBD): Determining Therapeutic Goals for Treat-to-Target strategies in IBD. Gastroenterology. 2021;160:1570-83.

9. van den Brink G, Stapersma L, Vlug LE, Rizopolous D, Bodelier AG, van Wering $\mathrm{H}$, et al. Clinical disease activity is associated with anxiety and depressive symptoms in adolescents and young adults with inflammatory bowel disease. Aliment Pharmacol Ther. 2018;48:358-69.

10. Trivedi I, Keefer L. The Emerging Adult with Inflammatory Bowel Disease: Challenges and Recommendations for the Adult Gastroenterologist. Gastroenterol Res Pract. 2015;2015:260807.

11. Lippmann J, Fock A, Arulanandam S. Cerebral arterial gas embolism with delayed treatment and a fatal outcome in a 14-year-old diver. Diving Hyperb Med. 2011:41:31-4

12. Williet N, Sandborn WJ, Peyrin-Biroulet L. Patient-reported outcomes as primary end points in clinical trials of inflammatory bowel disease. Clin Gastroenterol Hepatol. 2014;12:1246-1256.e6.

13. Levine A, Koletzko S, Turner D, Escher JC, Cucchiara S, De Ridder L, et al. ESPGHAN revised porto criteria for the diagnosis of inflammatory bowel disease in children and adolescents. J Pediatr Gastroenterol Nutr. 2014;58:795-806.

14. Satsangi J, Silverberg MS, Vermeire S, Colombel JF. The Montreal classification of inflammatory bowel disease: Controversies, consensus, and implications. Gut. 2006;55:749-53.

15. Varni JW, Seid M, Kurtin PS. PedsQLTM 4.0: Reliability and Validity of the Pediatric Quality of Life InventoryTM Version 4.0 Generic Core Scales in Healthy and Patient Populations. Med Care. 2001;39:800-12.

16. Varni JW, Limbers CA. The PedsQLTM 4.0 generic core scales young adult version: Feasibility, reliability and validity in a university student population. $\mathrm{J}$ Health Psychol. 2009; 14:611-22.

17. Jenkinson C, Coulter A, Wright L. Short form 36 (SF 36) health survey questionnaire: Normative data for adults of working age. Br Med J. 1993;306:1437-40.
18. Ferreira-Valente MA, Pais-Ribeiro JL, Jensen MP. Validity of four pain intensity rating scales. Pain. 2011;152:2399-404.

19. Brazilian Association of Research Companies - ABEP. Economic classification criterion Brazil. Abep. 2018;1:1-5.

20. Turner D, Otley AR, Mack D, Hyams J, de Bruijne J, Uusoue K, et al. Development, Validation, and Evaluation of a Pediatric Ulcerative Colitis Activity Index: A Prospective Multicenter Study. Gastroenterology. 2007;133:423-32.

21. Vermeire S, Schreiber S, Sandborn WJ, Dubois C, Rutgeerts P. Correlation Between the Crohn's Disease Activity and Harvey-Bradshaw Indices in Assessing Crohn's Disease Severity. Clin Gastroenterol Hepatol. 2010;8:357-63.

22. Schroeder KW, Tremaine WJ, Ilstrup DM. Coated Oral 5-Asa for Mildely To Moderately Active Ulcerative Colitis. N Engl J Med. 1987;24;317:1625-9.

23. Leso V, Gervetti P, Macrini MC, Russo F, Iavicoli I. Inflammatory bowel diseases and work disability: A systematic review of predictive factors. Eur Rev Med Pharmacol Sci. 2021;25:165-81.

24. Knowles SR, Keefer L, Wilding H, Hewitt C, Graff LA, Mikocka-Walus A. Quality of Life in Inflammatory bowel disease: a systematic review and meta-analyses - Part II. Vol. 24, inflammatory bowel diseases. Lippincott Williams and Wilkins; 2018. p. 966-76.

25. Ryan JL, Mellon MW, Junger KWF, Hente EA, Denson LA, Saeed SA, et al. The clinical utility of health-related quality of life screening in a pediatric inflammatory bowel disease clinic. Inflamm Bowel Dis. 2013;19:2666-72.

26. Stawowczyk E, Kawalec P, Kowalska-Duplaga K, Mossakowska M. Productivity Loss Among Parents of Children With Inflammatory Bowel Diseases in Relation to Disease Activity and Patient's Quality of Life. J Pediatr Gastroenterol Nutr. 2020;71:340-5.

27. McDermott E, Mullen G, Moloney J, Keegan D, Byrne K, Doherty GA, et al. Body image dissatisfaction: Clinical features, and psychosocial disability in inflammatory bowel disease. Inflamm Bowel Dis. 2015;21:353-60.

28. Karwowski CA, Keljo D, Szigethy E. Strategies to improve quality of life in adolescents with inflammatory bowel disease. Inflamm Bowel Dis. 2009;15:1755-64.

29. De Carlo C, Bramuzzo M, Canaletti C, Udina C, Cozzi G, Pavanello PM, et al. The Role of Distress and Pain Catastrophizing on the Health-related Quality of Life of Children with Inflammatory Bowel Disease. J Pediatr Gastroenterol Nutr. 20191;69:E99-104.

30. Peyrin-Biroulet L, Cieza A, Sandborn WJ, Coenen M, Chowers Y, Hibi T, et al. Development of the first disability index for inflammatory bowel disease based on the international classification of functioning, disability and health. Gut. 2012;61:241-7.

31. Hardin AP, Hackell JM, Simon GR, Boudreau ADA, Baker CN, Barden GA, et al. Age limit of pediatrics. Pediatrics. 2017;140:e20172151.

32. Silva CA, Terreri MT, Bonfa E, Saad-Magalhães C. Pediatric rheumatic disease patients: time to extend the age limit of adolescence? Adv Rheumatol. 2018;58. DOI: https://doi.org/10.1186/s42358-018-0031-y

33. van Rheenen PF, Aloi M, Biron IA, Carlsen K, Cooney R, Cucchiara S, et al. European Crohn's and Colitis Organisation topical review on transitional care in inflammatory bowel disease. J Crohns Colitis. 20171;11:1032-8.

34. Chouliaras G, Margoni D, Dimakou K, Fessatou S, Panayiotou I, Roma-Giannikou E. Disease impact on the quality of life of children with inflammatory bowel disease. World J Gastroenterol. 2017;23:1067-75.

35. Abdovic S, Pavic AM, Milosevic M, Persic M, Senecic-Cala I, Kolacek S. The IMPACT-III (HR) Questionnaire: A valid measure of health-related quality of life in Croatian children with inflammatory bowel disease. J Crohn's Colitis. 2013;7:908-15 